\title{
Subsidiary Business Networks and Opportunity Development in Multinational Enterprises: A Comparison of the Influence of Internal and External Business Networks
}

\section{Citation for published version (APA):}

Yamin, M., Ghauri, P. N. (Ed.), \& Hadjikhani, A. H. (Ed.) (2005). Subsidiary Business Networks and Opportunity Development in Multinational Enterprises: A Comparison of the Influence of Internal and External Business Networks. In Business Opportunity Development in Business Networks (pp. 91-109). Palgrave Macmillan Ltd. http://www.amazon.com/exec/obidos/ASIN/156720421X/qid\%3D1073676067/sr\%3D11-

1/ref\%3Dsr\%5F11\%5F1/102-0071178-5593717

\section{Published in:}

Business Opportunity Development in Business Networks

\section{Citing this paper}

Please note that where the full-text provided on Manchester Research Explorer is the Author Accepted Manuscript or Proof version this may differ from the final Published version. If citing, it is advised that you check and use the publisher's definitive version.

\section{General rights}

Copyright and moral rights for the publications made accessible in the Research Explorer are retained by the authors and/or other copyright owners and it is a condition of accessing publications that users recognise and abide by the legal requirements associated with these rights.

\section{Takedown policy}

If you believe that this document breaches copyright please refer to the University of Manchester's Takedown Procedures [http://man.ac.uk/04Y6Bo] or contact uml.scholarlycommunications@manchester.ac.uk providing relevant details, so we can investigate your claim.

\section{OPEN ACCESS}


Subsidiary Business Networks and Opportunity Development in Multinational Enterprises: A Comparison of the Influence of Internal and External Business Networks.

\author{
Mohammad Yamin \\ Manchester Business School, University of Manchester, \\ PO Box 88, Manchester, M80 1QD \\ England
}

I am grateful to Ulf Andersson, Amjad Hadjikhani and Ulf Holm who patiently listened to me and whose comments and questions were helpful to me in clarifying my ideas. .The usual caveat applies.

This paper is published in Ghauri, P Hadjikhani, A and Johanson, J (eds.) ( 2005) Business Opportunity Development in Business Networks. Routledge. In Press 


\section{$\underline{\text { Introduction }}$}

\section{The multinational enterprise and 'opportunity development'}

The objective of this paper is to make a contribution to understanding the nature of opportunity development within the multinational enterprise (MNEs). As explained in chapter one, opportunity development is broadly understood as new technological resource combinations and capability development.

Developments in the MNE literature strongly support a focus on opportunity development as a fruitful line of investigation. Thus whereas initially the literature on MNEs emphasised the exploitation of firm'sxisting knowledge and other 'ownership advantages' in foreign countries, there is now much greater interest in understanding the MNE's quest fornew sources of technological development and organizational competence ((Hymer 1976; Buckley and Casson 1976; Cantwell, 1989, 2000;Dunning 1993; Florida, 1997; Pearce, 1999; Almeida et al 2002). Other writers have expressed this development in terms of a shift of focus from asset exploiting and towards asset augmenting activities of MNEs. In this context, Dunning (1998) has highlighted 'strategic assetseeking' as being the most important motic behind MNE investment activity and a key factor in the MNE's competitive advantage (Dunning, and Lundun(1998).

Foreign subsidiaries play a significant and, arguably, critical role in the asset augmenting activities of MNEs (Yamin, 1999). There is now a realization amongst academic investigators that subsidiaries of many multinational firms have matured well beyond being 'miniature replicas' of their parents and have become increasingly 'creative' in a variety of directions (Bartlett and Ghosahall, 1989, 1990, Birkinshaw and Hood, 1998; Ghosahl and Bartlett, 1988, Pearce, 1999). In fact a number of writers have specifically stressed the mandate-developing and entrepreneurial roles often played by MNE subsidiaries (Birkinshaw, 1996; Birkinshaw, 1997; Yamin 2002; Regnér, 2003). Yamin (2002) has argued that the greater propensity for entrepreneurship on the part of foreign subsidiaries compared to the subunits of a national firm constitutes an important basis for the advantage of multinational.ity. Equally importantly, there is a similar realization amongst MNE decision-makers that foreign subsidiaries can play a role in asset augmenting activities. Thus a large survey reported that most MNE CEOs agreed that 'the primary role of our overseas units is to find out antake advantage of 
opportunities within the countries in which they operate' (Leung and Tan, 1993, Table 1, p. emphasis added).

\section{Study focus: subsidiary business networks and opportunity development}

Perhaps the most significant development in the MNE subsidiary literature, however, is the detailed investigation of the role of business networks in the process of opportunity development in the MNE (Andesson and Phalberg, 1997; Andesson and Forsgren 2000; Andersson and Holm, 2002; Andersson, et al 2001a; Andersson et al 2001b; Andersson et al 2002; Forsgren et el 1999; Holm and Pedersen, 2000). These studies have highlighted embeddedness in business networks, indicated by mutual adaptations in general business conducts between the subsidiary and its suppliers and/or its customers, as an underlying factor in knowledge creation in MNEs. Through their business interactions with their partners, subsidiaries develop technological and organisational competencies which, when transferred to other units, help to improve the overall level and range of the competencies within the MNE. More specifically, embeddedness in business relationship gradually develops into technical embeddedness which in turn drives technological and product development capabilities in the subsidiary. The subsidiary business network literature strongly confirms prior evidence, from a more general setting, that a business relationship develops into technological interdependencies between business partners and that these enhance the technological competence and innovative performance of partners (Lundvall; 1988; Von Hippel 1988; Tyre and Von Hippel 1997; Araujo 1999; Lane and Labutkin 2001). The subsidiary business network literature applies and develops this insight ('learning through interacting') in the specific organisational context of the MNE. It thus bears repeating that subsidiary embeddeness is arguably the foundation of the 'opportunity development' processes within MNEs. Given that the MNE, compared to a uni -national company, has a greater potential for tapping into a diversity of sources of knowledge and technology, subsidiary embddedness in business networks initiates a process that turns this potential into realizable opportunities for MNE's competence development.

Whist a subsidiary's business partners could be either sister affiliates in the MNE or external businesses; most of the attention has been paid to subsidiaries business relations with external businesses and to the impact of such relationships on the MNEs. With some exceptions (Andesson et al 2001; Schmid and Schuring 2003) internal business relations- that is, business relationships between affiliates of the 
same MNE, has not been the focus of empirical investigation. Most empirical studies only include measures /indicators of external business embddedeness in their analyses ${ }^{1}$.

Thus, broadly speaking, extant studies strongly imply that it is subsidiary embeddedness in external networks that really matters in this respect. However, given that internal embeddedness has thus far remained largely in the background, it may be rather premature to privilege external subsidiary embeddedness as the main, let alone the only source for 'opportunity development' in the MNE. Whether subsidiary embeddedness in internal business relationships can have similar consequences, in qualitative and quantitative terms, to external embddedness is still an open question.

This paper addresses the above gap ${ }^{2}$. Our approach is to start from 'first principles', asking two questions: (a) whether or under what conditions is a genuinely business relationship between internal partners a possibility? And (b) whether internal business relationships generate the kind of ongoing mutual technical interactions and adaptations that are usually associated with business network learning? For the purpose of the following discussion, a 'business' relationship always entails a commercial or a transactional dimension- the parties (internal and external actors) to the relationship are buyers and sellers. Thus, asking whether internal business relationships are possible, entails enquiring whether two parties that are already related to each other by virtue of being subsidiaries of the same firm can,

1 The findings relating to external subsidiary embddedeness are clearly robust as other studies not dependent on network analysis have also provided strong evidence not only that subsidiary innovations are frequently sourced from the local host environments (Almeida, 1996; Frost, 2001; Phene and Almeida 2003; Yamin and Otto, 2004) but also that subsidiaries grow 'progressively closer to local host country networks both in terms of sourcing and sharing knowledge' (Phene and Almeida, 2003).

2 In the paper we assume that a subsidiary's 'network focus' is either internal or external. A focal subsidiary has an internal (or corporate) 'network focus' if the majority of its key business partners are also subunits of the same MNE. A subsidiary's network focus is external if its key business partners are not subunits of the same MNE. A situation of 'balanced focus' -in which the key business relationships equally straddle the internal and external domains, is also a possibility. However the analysis of this paper will assume that network focus is binary and ignores the intermediate case. 
nevertheless, also become buyers and sellers and conduct their business according to commercial rather than administrative criterion.

In section 2.II below, we discuss this issue and conclude that, in theoretical terms, internal business relationships are certainly a possibility in the context of the federative MNE. However in section 2.III, we show that, again on theoretical grounds, internal embedded business relationships are less likely to generate 'deep' adaptations compared to externally embedded relationships. Thus in internal business relationship, 'learning through interacting' is a weaker process. In section 3 we develop propositions on how internal and external embdddedness of subsidiaries generate opportunities for competence development in the MNE. We focus on subsidiary 'organisational performance' by which, following Andersson, et al (2001b), we mean the impact of the subsidiary on the rest of the MNE through its knowledge development and knowledge sharing activities.

\section{Network Analysis and Inter-Subunit Business Relationships in MNEs}

\section{Background}

Although the network concept has been very influential in MNE research there are two quite distinct approaches to how the network concept is used in this research (Forsgren, 2004). In the following sub-section, we will rely to on both approaches to investigate whether internal business relationships are a possibility. First, we briefly indicate the distinctive aspects of the approaches.

One stream of literature adopts a contingency theory perspective in that it views the MNE as a particularly suitable organizational arena for a networking approach to management. There is a recognition that, because the MNE is inevitably a differentiated organisation, the traditional managerial reliance on hierarchy (e.g. centralization and formalisation) needs to be supplemented or even supplanted by a networking approach the building block of which is the essentially personal relationships that binds the management strata of the MNE into a more or less coherent team (Ghoshal and Nohira, 1989; 1997; Ghoshal, et al 1994; Tsai and Ghoshal, 1998; O’Donnel, 2000). The intra-firm network drives the process of exchange and value creation between different subunits of the MNE (Tsai and Ghoshal, 1998). This consideration is relevant to the emergence of business relationship between subunits as we shall discuss below. 
On the other hand there is a literature from the 'markets-as-networks' (MAN) perspective (McLoughin and Horan 2002; Forsgren, 2004). Here the starting point is the 'ordinary' business transaction between a buyer and a seller (a 'market' phenomenon) and its evolution, via increasing interdependence, into a business relationship (i.e. the building block of the business 'network' phenomenon). When applied to the analysis of the MNE, the initial focus has been on subsidiaries rather then the organisation as a whole although it is clearly acknowledged that subsidiaries are influenced both by their business networks and by the overall strategy of the MNE as determined by headquarters (Forsgren 2004).

\section{Are internal business relationships possible in MNEs?}

The relative neglect of internal business relationships and networks is partly explained by the fact intra-organisational interdependencies do not necessarily fit into the MAN perspective. The perspective implies independent organisations voluntarily engaging in a process entailing increasing interdependence with selected businesses partners (Johanson and Mattsson, 1994). Thus, strictly speaking, MAN may be inapplicable to organisational subunits as they lack ultimate decision authority. This, in principle, is equally true of subunits' internal and external partner interdependencies. However, in practice, a subsidiary's external partners are probably less 'visible' to the MNE headquarter (Holm et al 1995 ) and, more broadly, the assumption of organisational isolation between the MNE and the subsidiary has probably more substance in the case of externally embedded subsidiaries (Yamin, 2002).

A subsidiary's intra-firm interactions are more closely in the preview of the MNE decision makers and the interdependencies are less likely to develop into the sort of business relationships envisaged in the MAN perspective. There is probably a large element of 'logistic' delivery (of components or services) ${ }^{3}$. Logistic delivery entails a high degree of standardisation and the does not suggest the privileging or prioritising of particular inter-subsidiary relationships. If the interdependency between subsidiaries is only administrative in nature and consists only of logistic delivery, then a business relationship between subsidiaries cannot develop. The important thing is therefore that this sort of interdependence does

\footnotetext{
${ }^{3}$ A related phenomenon is indicated by the notion of operational flexibility articulated by Kogut (1983; 1990). Here subsidiaries tend to duplicate similar operations in different markets, rather than developing complementary activities. This again tends to limit the scope for of an business (customer, supplier) relationships.
} 
not lead to mutual adaptation in technological and production processes that the MAN view envisages (Belussi and Areangeli's 2001 'steady state' network type may apply here). Consequently, in such cases, inter-subsidiary interdependencies are not associated with 'opportunity development' in the MNE.

However the are a number of considerations suggesting that the possibility of internal business relationship within MNE cannot be ruled out. For one thing the scope for subsidiary manipulation by the centre in order to exercise operational flexibility should not be exaggerated as the centre often lacks the informational and organisational pre-requisites (Kogut and Kulatilaka, 1994). Empirical evidence indicates moderate degrees of operational flexibility at best (Ragan 1998). More generally the picture of a closely coordinated MNE is significantly at odds with reality ( consider Zander and Solvell's 'the phantom multinational') : most MNEs have experienced their recent expansion through acquisitions (Andersson et al 97; UNCTAD 2000; Zander and Solvell 2002) and by definition newly acquired subsidiaries are unlikely to be in any sense fully coordinated with the rest of the MNE system at least in the short term. However this does open up opportunities for the development of business relationship between sub units of the MNE.

From a theoretical perspective, the possibility of market or business relationships within hierarchies has been noted in the transaction cost/internalisation literature from Coase (1937) onwards. Buckley and Casson (1998) argue that increasing environmental volatility has generated an aversion to 'internal monopoly' within the MNE (p.28). Headquarters bureaucracies have come under increasing attack and have been to a degree supplanted by divisional centres (see also Forsgren et al 1995) with an attendant increase in sourcing autonomy at the division (and subsidiary?) level (Buckey and Casson, 1998, p. 32). Recent literature indicates a significant degree of subsidiary leverage for independent initiative and mandate building and whilst these are mostly developed through business relationship with external partners in the host country, the potential for internally focused business relationships is also acknowledged (Birkinshaw 1996; Birkinshaw and Ridderstrale 1999; Buckley and Casson 1998). This last observation is strongly linked with the 'networking' perspective in MNE. It is the recognition of the unworkability of an exclusively hierarchical and top-down approach to managing the MNE that has driven the search for an 
alternative approach. Ghoshal and Bartlett's (1990) advocacy of viewing the MNE as a federative rather than a unitary organization was an important step in this direction. Since then there has been much emphasis on the value of intraorganisational network of relationships among the MNE management strata. Most recently this basic view has been articulated through the application of the 'social capital' concept to intra-MNE relationships (Tsai and Ghoshal 1998; Tsai, 2000; Kostova and Roth, 2003). Dimensions of organisational social capital, in particular, 'social interactions' ${ }^{, 4}$ and 'mutual trust' are shown to drive the process of resource (information, products, personnel and support) exchange and combinations between different subunits (Tsai and Ghoshal, 1998). Whist such resource exchanges are a manifestation of intra-organisational solidarity rather than of ongoing business interactions (as between suppliers and customers) the former can open up opportunities for the latter. For example the exchange of personnel between sub-units may help the subunits to identify mutually profitable business opportunities.

In conclusion, we believe that three factors argue for increasing opportunities for business relationships between MNE subunits:

1. The 'flattening' of MNE hierarchy and increasing scope for subunit initiatives

2. Increasing sub unit capability for mandate development focussed on internal or external business opportunities.

3. The emergence of the federative MNE and the formation of inter-subunit networks within them.

\section{Features of internal and external business relationships.}

Even when inter-subsidiary business relationships are established they may be somewhat different from business relationships with external partners. The crucial issues, in terms of subsidiary role in the opportunity development process (with respect to technological competence in the MNE), is whether internal business

\footnotetext{
${ }^{4}$ It is perhaps noteworthy that physical distance/ proximity does not seem to be a factor in intraorganisational social interactions.Thus respondents in Tasi and Ghoshal, $(1998,468)$ are managers of units in different countries who nevertheless engage in high degrees of social interactions with each other. This perhaps reflects the very narrow basis for 'social' capital in the organisation; participants are exclusively at the very zenith of the organisation who do not face the kind of inconvenience and effort that are normally involved in frequent travel (i.e. they may have access to private company jets and private airports and bypass the congestion of major airports and scheduled flights). For a different, 'damage-of-distance', view of intra-organisational social interactions see Goodall and Roberts (2003). See also page 16 for further discussion of this issue.
} 
relationship generate significant technical and production adaptations, as these are viewed as the a key source for competence development in the subsidiary and thus its ability to contribute to competence development in the MNE as a whole.

In this section we consider four factors affecting the 'productivity' of a business network for the subsidiary. Table 1 lists the factors and their consequences for internal and external networks. 
Table 1: SUBSIDIARY BUSINESS NETWORK: INTERNAL VERSUS EXTERNAL BUSINESS NETWORKS

\begin{tabular}{|l|l|l|l|}
\hline $\begin{array}{l}\text { Factors affecting } \\
\text { network formation/ }\end{array}$ & \multicolumn{1}{|c|}{$\begin{array}{c}\text { Internal } \\
\text { business } \\
\text { networks }\end{array}$} & $\begin{array}{c}\text { External } \\
\text { business network }\end{array}$ & $\begin{array}{c}\text { Consequences for the } \\
\text { subsidiary }\end{array}$ \\
\hline $\begin{array}{l}\text { Influence of corporate } \\
\text { context }\end{array}$ & High & Low/medium & $\begin{array}{l}\text { Internal network likely to } \\
\text { have activity focus closer to } \\
\text { MNE 'dominant logic' than } \\
\text { external networks. }\end{array}$ \\
\hline Control by HQ & High & Low & $\begin{array}{l}\text { Investment in internal } \\
\text { business networks more } \\
\text { constrained by the MNE's } \\
\text { 'internal capital market'. }\end{array}$ \\
\hline $\begin{array}{l}\text { Initial (non- } \\
\text { administrative) } \\
\text { interdependencies } \\
\text { generated via }\end{array}$ & $\begin{array}{l}\text { Managerial } \\
\text { networks }\end{array}$ & $\begin{array}{l}\text { Market } \\
\text { transactions } \\
\text { adaptations in external } \\
\text { networks. }\end{array}$ \\
\hline $\begin{array}{l}\text { Location and geography } \\
\text { nore likely to be }\end{array}$ & $\begin{array}{l}\text { More likely to be } \\
\text { in host country. }\end{array}$ & $\begin{array}{l}\text { Internal networks subject } \\
\text { to a greater degree of } \\
\text { 'damage of distance'. }\end{array}$ \\
\hline
\end{tabular}


All subsidiaries have to operate within a corporate context that has been shaped by various factors. One particularly relevant aspect is the notion of managerial 'dominant logic' (Bettis and Prahalad, 1986; 1995). Dominant logic is an information filter; 'organisational attention is focussed on data deemed relevant by the dominant logic. 'Other data are largely ignored... the 'filtered' data are then incorporated into the strategy, systems and values' (Bettis and Prahalad, 1995, p.). The notion of environmental filtering is also strongly present is Penrose's theory of the growth of the firm - where investment plans are largely defined by the firm's 'productive opportunity'. Productive opportunity is a 'perceptual' boundary of what firms can and cannot do successfully (Penrose, 1959). The dominant logic of the organisation clearly affects the behaviour and choices of subunits. In fact in the Bettis and Prahalad (1995) view 'behaviour reinforcement' is an important aspect of the concept. In the context of foreign subsidiaries, Birkinshaw and Ridderstarle (1999) have shown that, what they call 'corporate immune system', constrains the subsidiary initiatives.

However it is reasonable to expect that subsidiaries that have corporate or internal business ties and relationships will be more tightly constrained by the corporation dominant logic. Thus the network context of internal relationship inevitably includes other MNE subsidiaries, all connected to the parent for various business or administrative reasons. The most important player in the network context is usually the HQ itself. Because the HQ is the 'custodian' of the dominant logic of the enterprise as a whole it is bound to take a keen interest in how inter-subsidiary relations develop and would exercise its power and authority to influence these business relationship in a direction supporting or reinforcing the dominant logic.

On the other hand externally embedded subsidiaries are probably more able to develop business initiatives in new directions. This is partly due to their relatively higher degree of organizational autonomy (Yamin, 2002) and their ability to 'hide' initiatives (from the centre) until they are a faith-accompli (Birkinshaw and Ridderstralle 1999). It is also partly due to externally embedded subsidiaries being more likely to adopt an 'inductive' approach to opportunity or initiative definition based more on trail and error. By comparison the HQ approach to business opportunity definition is likely to be more 'deductively' based and follow more 
closely existing industry 'recepies' and within the trajectory of MNE's current competencies (Yamin 2002; Regner, 2003).

In addition to its role as a member of the subsidiary's network context, the HQ has formal control authority that it can exercise to further reinforce subsidiary conformity. It has been argued that MNE headquarters effectively act as an internal capital market (Mudambi, 1999); a principle consideration for the MNE headquarter is control over the investment resources of the subsidiary to ensure that one subsidiary's investment does not 'crowd out' investment opportunities for other subsidiaries. However it is likely that this HQ function is more easily carried out with respect to internally embedded subsidiaries; internal network embeddedness enhances HQ control over the subsidiary (Andersson and Forsgren 96; Holm et al 1995). Externally embedded subsidiaries are likely to have greater degrees of strategic autonomy and enjoy greater freedom in investment decisions (Mudambi, 1999). Thus the MNE is in a stronger position to influence or even direct the development of business relationships within the internal network. Consequently, mutual adaptations that do take place in internal networks are likely to be limited in scope.

External business relationships are also shaped by the surrounding network context. Furthermore the HQ is normally an important node in this context too, but the nature of the relationship between the network context and the focal relationship is clearly fundamentally different in the two cases. The HQ is less of a pivotal influence in the externally embedded subsidiary's network. Previous studies show that the MNE HQ is not necessarily very familiar with the subsidiary's external business relationships and that this tends to weaken its control over the focal subsidiary (Holm, et al 1995; Andersson and Forsgren 1996, 2000; Medcof, 2001). In particular subsidiary investment in business relationship enjoys some effective autonomy as the subsidiary is less dependent on internal funding to develop its business relationships. Thus in comparison to internally embedded relationships, external relationship are less circumscribed or bounded by their network context. Potentially at least, mutual adaptations in external networks are likely to be more 'creative'. 
Thirdly, mutual adaptations are likely to be less 'frequent' in internal relationships and networks Adaptation in a business relationship implies (or in fact requires) initial ignorance of partner characteristics. Business relationships evolve from arms -length transactions with particular customers and suppliers. Therefore, at least initially, adaptation is a consequence of the discovery of partner characteristics (and needs) and of the investments opportunities that the accommodation to the partner opens up. Internal business relationships do not necessarily start life as transactions (see above). By virtue of their membership of the organisation they are already tied to each other by information flows of not only an administrative nature but also by some degree of knowledge flows (Gupta and Govindrajan, 1991; 2000). This is strongly reinforced by the practice of networking in the organization. As we have already indicated, inter-subunit network relationships are associated with inter-subunit resource transfers including information, product and personnel between subunits. Thus the potential business partners are to some degree known to each other and quite possibly internal business partners may be selected or mutually come together because they are already (perceived to be) somewhat compatible and hence because the required adaptation is perceived to be either absent or minor. Of course the relationship may develop in a way that will necessitate significant adaptations by the partners over time. However, if we assume that business relationships are path-dependent then internal relationships may get stuck in a low-adaptation trajectory. In particular, the enduring influence of the managerial network may encourage interactions mainly at or through the management strata at the subunits. But business network adaptations are a source of value creation because they entail multiple and interacting functional and operational interdependencies. The interactions are not purely or even mainly 'managerial' but involve the whole organisation including operational and routine activities as well. Thus business adaptation is defined as the close coordination of inter-partner dependencies that helps to create 'an efficient workflow system'5 (Blakenberg Holm, et al 1999, p.

${ }^{5}$ The work flow concept has usually been employed with respect to intraoraganisational interdependencies in which a number of subunits are closely organised (Astely and Zac 1990; 1991). Thus it seems that business relationship are productive (of value) to the extent that they mimic a closely coordinated multi -unit organisation - at least in some respects(?). One interpretation could be that intra- organisational coordination is achieved through discrete design from the centre whereas in business relationships the coordination is an emergent process accompanied by organisational learning. Thus if the MNE is actually a 
47, my emphasis). We suggest that adaptations are 'deep', if they are generated through interactions at all levels of the value chain and involve the organisations a $\mathrm{s}$ whole ratter than only a small group within the organisation ( see also Tsoukas, 1996, p. 22)

Finally, there is the issue of location. In a multinational firm, inter-subsidiary networks will almost inevitably be cross- border (if the subsidiaries are in the same country then they are likely to be highly integrated and exchanges between them will be of the 'logistic' type. Thus, for example interactions between a production subsidiary and an R\&D subsidiary in the same country will be of this sort). In the context of supplier customer relationships, the significance of location is fully indicated by Trye and Von Hippel (1997). They argue that adaptive learning has a 'situated' dimension - meaning that intimate knowledge of the physical context of partner value adding activity is a critical part of the process. Situated learning does not merely require 'co-presence' but specifically physical presence and close familiarity with partner activates in their location or situation. Importantly, 'communication' is a poor substitute for situated learning. Goodall and Roberts (2003) also emphasise the connection between organisational knowledge and situated action. It is the situated nature of knowledge acquisition (and knowledge maintenance) that they argue is the basis of the 'damage' of distance.

It follows from the above that inter-subsidiary relationships will be constrained by geographical distance. Considering that business relationships entail interaction (and hence frequent travel) by functional and operational personnel and not merely the top management (who, as suggested in footnote 4, may enjoy exclusive travel facilities), we can surmise that cross border business relationship may be at a disadvantage. By contrast relationships between a subsidiary and external partners are more frequently (but not always) in the host country and often in the same region or locality within the host country. Thus they are more likely (than internal relationships) to benefit from proximity. This

fully coordinated system then the prospect for internal business relationships are limited. The subsidiaries have well adapted and coordinated roles defined and managed centrally. In this scenario we are back in the situation in which inter subsidiary exchanges are of the logistical type (cf 'steady state' networks). 
reinforces the chances of having 'deeper' adaptations in externally focussed subsidiary business relationships.

\section{Network Focus and Subsidiary Organisational Performance in the MNE}

In the previous section we have focussed on subsidiary network relationship and the considered the (possible) differential impact of internal and external networks on the subsidiary. The conclusion is that, compared to externally embedded subsidiaries, internal business relationships are (a) subject to greater control by parent and are more constrained by the corporate context; and (b) have a 'narrower' and 'shallower' pattern of business interactions. In this section we consider the implications of these for subsidiary organizational performance.

\section{I- Subsidiary role in knowledge transfer to other MNE units.}

It follows from the above that internally embedded subsidiaries are more likely to develop knowledge and competence that is closer to the MNE current 'dominant' logic. They are closely tied to the MNE HQ is terms of the direction of the development of their activities. In particular their technological and innovative activities are likely to remain close to the parent firm technology 'trajectory' (Pearce, 1999). By contrast, externally embedded subsidiaries develop knowledge and competence that is more likely to be differentiated from that of the MNE. If we adopt Gupta and Govindrajan's (2000) terminology, we can suggest that the externally embedded subsidiaries create a higher percentage of non- duplicative knowledge, whereas the internally embedded subsidiaries create a greater percentage of duplicative knowledge (see also Frost 2001).

However all subsidiaries have a combination of duplicative and nonduplicative knowledge. The duplicative component is generally sourced from internally coordinated activities (including subsidiary's R\&D, see Foss and Pedersen 2002) and other internally networked business relationships. Non-duplicative knowledge is sourced from the foreign location of the subsidiaries but is usually developed through business relationship with specific customers and suppliers (which could be either sister affiliates or other external businesses). Knowledge transfer requires both duplicative and non-duplicative components. The non-duplicative component gives the knowledge a value whereas the duplicative component creates absorptive capacity for the recipient. Internally embedded subsidiaries are likely to have a 'better' combination of duplicative and non-duplicative knowledge. The non- 
duplicative component of the knowledge is developed within internal business relationship and is therefore developed in a relatively familiar business context to the sister affiliates. Therefore is going to be perceived as 'relevant' new knowledge (Gupta and Govindarajan 2000). By contrast externally embedded subsidiary's are likely to have a non-duplicative knowledge base that is shaped mainly by its business ( and consequently technological) embeddedness in business relationship with external partners ( Lane and Lubatkin, 1998). Thus the non-duplicative knowledge is likely to be further away (relative to that of internally embedded subsidiaries) from that of parent and the sister affiliates. Based on these considerations we put forward the following proposition.

Proposition 1: internally embedded subs transfer knowledge to the MNE more frequently than externally embedded subsidiary.

\section{II-Subsidiary contribution to MNE production and product development.}

What is the outcome of such knowledge transfer though likely to be? I suggest that frequent knowledge transfer will be focussed mainly on current production activities and will have a mainly 'adaptive' character (Frost 2001) in the sense that it helps to spread 'best' practice ( Szulanki 96; Maritan and Brush 2003) in relation to the current value chain activities of the recipients. The main focus of the knowledge transfer and development in internal business relationship is on current production activities ('programmes of exploitation', March 1991). Externally embedded subsidiaries are less likely to be important to sister subsidiaries for the purpose of production development as they have knowledge that is likely to be less relevant in this respect. Thus we put forward the following proposition:

Proposition 2: internally embedded subsidiaries are more important than externally embedded subsidiaries for MNE production developments

Externally embedded subsidiaries are (relative to internally embedded) are more loosely tied to the MNE. Thus even though they are less frequently or intensively involved in knowledge transfer or development in the MNE, they are likely to be the source of somewhat more novel and possibly more strategically valuable new knowledge for the MNE. In terms of Hansen's analysis of knowledge sharing across organisational subunits, 'weak-coupling' between sub units has the advantage of offering greater 'search' opportunities for identifying novel ideas, 
concepts and practices useful in product development and innovative activities of the searching subunit (Hansen, 1999, 2002). This suggests that the relatively low levels of knowledge transfers that do take place between the externally embedded subsidiaries and the MNE are likely to be potentially more productive as there is significant scope for cross-unit learning. In a tightly coupled organisation, in which cross-unit contacts and knowledge flows are both frequent and intensive, subunits have full knowledge of each other's capabilities, and the chances of finding useful novelty is absent or low (see also Ahuja, 2000; Ruef, 2002). Empirical evidence suggests that internally sourced knowledge transfers are not very productive (e.g. in terms of patent citations and 'knowledge- building' (Phne and Almeida 2003; Yamin and Otto 2004). Therefore we suggest that knowledge transfers involving externally embedded subsidiary, although less frequent, is likely to be somehow more significant and 'eventful'. For example, externally embedded knowledge transfer is more likely to be organised on a discrete basis through a product development project teams rather than take place informally (Hedlund and Ridderstrale 1995; Subramaniam et al, 1998). Thus we put forward the following proposition:

Proposition 3: externally embedded subsidiaries are more important than internally embedded subsidiaries for MNE product development.

\section{Subsidiary influence on MNE strategy}

If subsidiaries are perceived as 'important' for production or product development in the MNE, that, potentially is a basis for their ability to exercise influence. In this sense power to influence has a resource dependency foundation (subsidiary have something - specifically technological and market based competence - that the MNE values). Andersson and Phalberg (1997) define influence as 'informal attempts to affect issues and behaviour indirectly' (p. 321) and argue that while subsidiaries do not have authority (which rests exclusively with the parent) they have the ability to influence strategy. With the exception of Andesson and Phalberg's early study there has up to now been little direct focus on subsidiary influence as such. However previous studies have clearly demonstrated that the some subsidiaries possess precondition for influence. For example, a subsidiary's elevation to the status of a 'centre of excellence' is a reflection of the value that other subunits (and in 
particular the HQ) attach to its perceived competence and (indirectly perhaps) to its network relationships (Andersson and Forsgren 2000).

In a recent paper, Andersson et al (2004) point out that up till now the literature has focussed on the subsidiary's 'negative' power - its power to escape or reduce control over its activities by the HQ. They argue that in a federative MNE, whilst formal power (authority) is vested at the HQ, organizational power is in fact distributed amongst the members of the federation; the key source of power for subsidiaries is their network embeddedness; whist the HQ sources of power are its 'legal' authority over strategic decision but also to a certain degree its (independently acquired) knowledge of the subsidiaries network base.

Thus we would expect that both internally and externally embedded subsidiaries will have some influence over MNE strategy as both have resources that are important (and hence of value) to the rest of the MNE. However we would hypothesise that the externally embedded subsidiary has greater influence on MNE strategy (and specifically on technology and product development strategy). There are three reasons for this. Firstly we have argued in the previous section that externally embedded subsidiaries are likely to be perceived as 'important' in relation to their product development contributions. From the perspective of the MNE, and in particular from the perspective of the MNE headquarter, the externally embedded subsidiary occupies a valuable position in a 'structural hole' (Burt 1992) indirectly linking the MNE to important sites of technological and market expertise. Secondly this is reinforced by the fact that MNEs are increasingly emphasising 'strategic asset seeking' investments. Dunning highlights this as the "most significant change in the motives for FDI over the last two decades' (Dunning 1998, p. 50). Gaining strategic assets is not purely a question of locating activities in a host environment with particular business system/ innovation systems characteristics but often also requires the development of close business relationship with businesses operating in that environment (Forsgren et al 2000). Clearly externally embedded subsidiaries are a much more likely site for MNE strategic assets developments than internally embedded ones as the latter already operate in broadly a similar range of product and technology field as the parent. Finally, previous research has indicated that the network context of externally embedded subsidiaries is relatively opaque to the MNE headquarter and the MNE is dependent on the subsidiary in transferring such embedded competence to elsewhere in the MNE (Andersson and Holm 2002). 
Internally embedded subsidiaries have a somewhat different resource basis with which to negotiate for influence within the MNE. Internally embedded subsidiaries are valuable mainly because they enhance the MNE's current operational efficiency by facilitating relatively smooth transfer of 'best practice'. Influence over product development can be viewed as a reward for such subsidiaries. The MNE may cede a degree of influence to such subsidiaries to keep them on board. By comparison, the MNE is relatively more dependent on externally embedded subsidiaries as they are likely to make direct contribution to developing MNE technology in new directions. The above discussion suggests the following propositions:

Proposition 4: externally embedded subsidiaries have a greater strategic influence on the MNE product/ technology development strategy the MNE than internally embedded subsidiaries.

Proposition 5: the influence path of internally embedded subsidiaries is through knowledge transfer and MNE production development.

Proposition 6: the influence path of externally embedded subsidiaries is through MNE product and technology development.

\section{Concluding Remarks}

The main conclusion of this paper is that while intra- MNE business relationships are certainly a possibility- they are likely to have a set of distinctive characteristics. Returning to the notion of the opportunity development process, we can see from the analysis of the appear that internally embedded subsidiaries do play a distinctive role in the process. Broadly speaking internally embedded subsidiaries contribute more to the MNE programmes of exploitation rather than to programmes of exploration (March 1991). Nevertheless these subsidiaries create significant opportunities for efficiency enhancement in the MNE mainly through the knowledge transfer process.

A broader conclusion is that the neglect of internal subsidiary embeddeness is theoretically unwarranted and thus that empirical investigation of the consequences of internal subsidiary embddedness is necessary. In the absence of such empirical evidence our knowledge regarding the role of subsidiaries in opportunity development in MNE is severely limited. 


\section{Bibliography}

Ahuja, G 2000 'Collaboration networks, structural holes and innovation: a longitudinal study’ Administrative Science Quarterly. 45, 425-455.

Almeida P. Song, J and Grant R. 2002 Are firms superior to alliances and markets? An analysis of cross border knowledge building. Organisation Science 13(2), 147-161

Andersson, M, Holm, U and Holmstrom, C (2001) 'Relationship configuration and competence development in MNC subsidiaries' in Hakansson, H and Johanson, $\mathrm{J}$ (Eds.) Business Network Learning. London: Pergamon

Andersson,U and Forsgren, M.(1996) 'Subsidiary embeddedness and control in the multinational corporation’ International Business Review. 5(5), 487-508.

Andersson, U. Johanson, J and Vahlne, J-E (1997) Organic acquisition and the internationalisation of the business firm' Management International Review 37 (2), $67-84$.

Andersson U and Pahlberg, C. (1997) 'Subsidiary influence and strategic behaviour in MNCs: an empirical Study’ International Business Review 3, 319-334.

Andersson, U and Forsgren M (2000) 'In search of centres of excellence: network embeddedness and subsidiary roles in multinational corporations' Management International Review 40(4), 329-350.

Andersson, $\mathrm{U}$ and Holm U (2002) Managing integration of subsidiary knowledge in the multinational corporation- a note on the role of headquarters. In Havila, V, Forsgren, M and Håkansson, H (eds.) Critical Perspectives on internationalisation. London: Elsevier

Andersson, U. Forsgren, M and Holm, U (2001a) 'Subsidiary embeddedness and competence development in MNCs- a multi-level analysis' Organization Studies 22(6) 1013-1034.

Andersson, U., Forsgren, M., and Pedersen, T. (2001 b) 'Subsidiary performance in multinational corporations: the importance of technology embeddedness'.

International Business Review. 10, 3-23

Andersson, U. Forsgren, M and Holm, U (2002) 'the strategic impact of external networks: subsidiary performance and competence development in the multinational corporation' Strategic Management Journal 23, 979-996

Andersson, U. Forsgren, M and Holm, U (2004) 'Fighting for power: subsidiary influence on strategic decisions in the federative MNC' Unpublished paper, Department of Business Studies, Uppsala university.

Arajuo, L (1998) 'Knowing and learning as networking' Management Learning. 29(3), 317-336. 
Astley G and Zac J (1990) 'Beyond dyadic exchange: functional interdependence and subunit power' Organization Studies 11(4), 481-501.

Blankenburg Holm, D, Eriksson, K and Johanson, J (1999) 'Creating value through mutual commitment to business network relationships' Strategic Management Journal 20, 467-486.

Belussi, F. and Areangeli, F. (1998). 'A typology of networks: flexible and evolutionary firms' Research Policy. 27, 418-428

Bettis, R and Prahalad, C. (1986) 'The dominant logic : a new linkage between diversity and performance' Strategic Management review 7(6), 485-501.

Bettis, R and Prahalad, C. (1995) 'The dominant logic: retrospective and extension' Strategic Management Journal 16, 5-15.

Birkinshaw, J. (1996) 'How multinational subsidiary mandates are gained and lost', Journal of International Business Studies27(3), 467-495.

Birkinshaw, J. (1997) 'Entrepreneurship in Multinational Corporations: The Characteristics of Subsidiary Initiatives' Strategic Management Journal 3, 207-230.

Birkinshaw, J and Hood, N. 1998 Multinational subsidiary evolution: capability and charter change in foreign-owned subsidiaries' Academy of Management Review 23 (4), 773-796

Birkinshaw, J., Ridderstrale, J. (1999). 'Fighting the corporate immune system: a process study of subsidiary initiatives in multinational corporations'. International Business Review, 8, 149-180.

Buckley, p and Casson M (1976) The Future of the Multinational Firm London: Macmillan

Buckley, P and Casson, M (1998) 'Models of the multinational enterprise' Journal of International Business Studies 29(1) 21-44.

Burt, R (1992) Structural Holes: The Social Structure of Competition. Cambridge, Mass: Harvard University press

Cantwell, J. (1989) Technological Innovations and Multinational Corporations, Blackwell, Oxford.

Cantwell, J (2000) 'Theories of International production' in Pitelis C and Sugden, R (eds.) The Nature of the Transnational Firm (2 ed.) London: Routledge

Coase, R (1937) 'The nature of the firm'. Economica, 4, 386-405. 
Dunning, J. (1993) Multinational Enterprise and the Global Economy . Wokingham: Addison-Wesley.

Dunning J (1998) 'Location and the multinational enterprise: neglected factor? Journal of International Business Studies 29(1) 45-66.

Dunning, J and Lundun, S 1998. The geographic source of competitiveness of multinational enterprise: an econometric analysis International Business Review 7(2) 115-134.

Florida, R. 1997. The globalisation of R\&D. Research Policy, 26, 85-103

Forsgren, M. Holm, U. and Johansen, J. (1995) 'Division headquarters go abroad- a step in the internationalisation of the multinational' Journal of Management Studies 32(4), 475-491.

Forsgren, M. Pedersen, T. and Foss, N. (1999). 'Accounting for the strength of MNC subsidiaries: the case of foreign-owned firms in Denmark' International Business Review 2, 181-196.

Forsgren, M, Johansen, J and Sharma, D (2000) 'The development of MNC centres of excellence' in Holm, $\mathrm{U}$ and Pedersen, T (eds) The emergence and Impact of MNC Centres of Excellence. London : Macmillan

Forsgren, M (2004) 'Use of network theory in MNC research' in Mahanke,V. and Pedersen, T (eds) Knowledge Flows, Governance and the Multinational Enterprise: Frontiers in International Management Research London :Palgrave.

Foss, $\mathrm{N}$ and Pedersen, $\mathrm{T}$ (2002) 'transferring knowledge in MNCs: The role of sourcing of subsidiary knowledge and the organizational context' Journal of International Management 8, 49-67.

Frost, T (2001) 'The geographic sources of foreign subsidiaries' innovations'. Strategic Management Journal. 22, 101-123

Ghoshal, S. and Bartlett, C. (1990) 'The multinational corporation as an interorganizational network' Academy of Management Review 15(4), 603-625

Ghoshal, S. and Nohria, N. (1997) The Differentiated MNC: Organizing Multinational Corporations for Value Creation. San Francisco: Jossey-Bass Publishers

Goodall, K and Roberts, J. (2003) 'Repairing managerial knowledge-ability over distance’ Organization Studies 24(7), 1153-1175. 
Gupta, A and Govindrajan V (1991) 'Knowledge flows and the structure of control within multinational corporations' Academy of Management Review 16(4), 768-792

Gupta, A and Govindrajan V (2000) 'Knowledge flows within multinational companies’. Strategic Management Journal 21,473-496.

Hansen, M (1999). The search-transfer problem: The role of weak ties in sharing knowledge across organisational subunits' Administrative Science Quarterly 44 pp. 82-111.

Hansen, M (2002). 'Knowledge networks: explaining effective knowledge sharing in multiunit companies'. Organization Science. 13(3), 232-248

Hedlund, G and Ridderstrale, J (1995) 'International development projects: key to competitiveness, impossible or mismanaged' International Studies in Management and Organisation, 25(1-2), 156-184

Holm, U and Pedersen, T (eds) (2000) The Emergence and Impact of MNC Centres of Excellence. London: Macmillan.

Holm U Johanson J and Thilenius P. (1995) 'Headquarters knowledge of subsidiary network contexts in the multinational corporations' International Studies of Management and Organisation 1-2, 97-120

Hymer, S. (1976) The International operations of national Firms Cambridge, Mass.: MIT press

Johanson, J and Mattsson L-G (1994) 'The markets as networks tradition in Sweden' in Laurent, G. Lilien G L and Prass B (eds.) Research Traditions in Marketing. Boston: Kulwer.

Kogut, B. (1983) 'Foreign direct investment as a sequential process' in C. P. Kindelberger and D. Audresch The Multinational Corporation in the 1980s. Cambridge, Mass.: MIT Press

Kogut, B. (1990) 'International sequential advantages and network flexibility' in Bartlett, Doz and Hedlund, G. (eds.)Managing the Global Firm.London :Routledge

Kogut, B. and Kulatilaka, N. (1994) Operating flexibility, global manufacturing, and the option value of a multinational network' Management Science. 40 (1),

Kotsova, T. and Roth, K. (2003) 'Social capital in multinational corporations and a micro-macro model of its formation'Academy of Management Review29(2), 297-317

Lane, P. and Lubatkin, M. 1998. Relative absorptive capacity and interorganisational learning' Strategic Management Journal 19(5), 461-477 
Leong, S. and Tan, C. (1993) 'Managing across borders: an empirical test of the Bartlett and Ghoshal organisational typology' Journal of International Business Studies 24, 3449-464.

Lundvall, B. (1988) 'Innovation as an Interactive Process: From User-Producer Interaction to National Systems of Innovation' in Dosi, et al (eds.), Technical Change and Economic Theory. Pinter, London.

March, J. (1991) 'Exploration and exploitation in organisational learning'Organisation Science, 1: 15-28.

McLoughim, D and Horan, C (2002) 'Markets as networks: notes on a unique understanding'. Journal of Business Research 55, 535-543

Medcof, J. (2001) 'Resource-based strategy and managerial power in networks of internationally dispersed technology units' Strategic Management Journal. 22, 9091012.

Mudambi, R. (1999) 'MNE internal capital market and subsidiary independence' International Business Review 8,197-211

O'Donnell, S. 2000 'Managing foreign subsidiaries; agents of the headquarters or an interdependent network?' Strategic Management Journal, 21, 525-548

Pearce, R. (1999) 'The Evolution of Technology in Multinational Enterprises: The Role of Creative Subsidiaries' International Business Review 2, 125-148.

Penrose, E (1959) The Theory of the Growth of the Firm. Oxford: OUP

Phne, A. and Almeida, P. (2003) 'How do firms evolve? The patterns of technological evolution of semiconductor subsidiaries'. International Business Review. 12, 349-467.

Ragan, S (1998) 'Do Multinationals Operate Flexibly? Theory and Evidence' Journal of International Business Studies 29(2)217-237

Regnér, P. (2003) 'Strategy creation at the periphery: inductive versus deductive strategy making' Journal of Management Studies 40(1), 57-82.

Ruef, M. 2002. Strong ties, weak ties and islands: structural and cultural predictors of organisational innovation. Industrial and Corporate Change, 11(3), 427-449.

Schmid, S. and Schuring, A. (2003). 'The development of critical capabilities in foreign subsidiaries: disentangling the role of the subsidiary's business network' International Business Review. 12, 755-782.

Subramaniam M, Rosenthal, S and Hatten, K (1998) 'Global new product development processes: preliminary findings and research propositions' Journal of Management Studies 35, 773-796. 
Szulanki G. (1996) 'exploring internal stickiness: impediments to transfer of best practice within the firm' Strategic Management Journal, 17, 27-24.

Tasoukas, H. (1996) 'The firm as a distributed knowledge system'. Strategic Management Journal. 17 (special issue), 11-25.

Tsai, W. and Ghoshal, S. (1998) 'Social capital and value creation: the role of intrafirm networks' Academy of Management Journal 41(4), 464-476.

Tsai, W (2000) 'Social capital, strategic relatedness and the formation of intraorganizational linkages’ Strategic Management Journal 29(2), 297-317.

Tyre, M. and Von Hippel, E. (1997) 'The situated nature of adaptive learning' Organization Science 8(1), 71-83.

UNCTAD (2000) World Investment Report 2000: Cross-Border Mergers and Acquisitions. New York: United Nations.

Von Hippel, E. 1988.The Sources of Innovations Oxford: Oxford University Press

Yamin, M (1999) 'An evolutionary analysis of subsidiary innovation and reverse transfer in multinational enterprises' in Burton, F Chapman, $\mathrm{M}$ and Cross, A (eds.) Multinational Enterprises, Transaction Costs and Internal organisationondon:

Macmillan

Yamin, M (2002) 'Subsidiary entrepreneurship and the advantage of multinationality' in Havila, V. Hakanson,H and Forsgren, M.(eds.) Critical Perspectives on Internationalisation. London: Elsevier

Yamin, M and Otto, J (2004) 'Patterns of knowledge flow and MNE innovative performance' Journal of International Management 10(2)

Zander, I. and Sölvell, O. (2002) 'The phantom multinational' in Havila, V. Hakanson,H and Forsgren, M.(eds.) Critical Perspectives on Internationalisation. London: Elsevier 